\title{
The Irabu Knoll: Hydrothermal Site at the Eastern Edge of the Yaeyama Graben
}

\author{
Tatsuhiro Fukuba, Takuroh Noguchi, and Teruo Fujii
}

\begin{abstract}
The Irabu Knoll hydrothermal vents were first discovered in 2000 during YK00-06 cruise using R/V YOKOSUKA and manned submersible SHINKAI 6500. The Irabu Knoll consists of three seamounts from 1,680 to $1,970-\mathrm{m}$ in water depth. The Irabu Knoll is located in the Southern Okinawa Trough and is constructed from basalt as the host rock. Two hydrothermal venting sites have been found at East and West seamount. Sulfide deposit of the Irabu Knoll hydrothermal system consists of barite, sphalerite, pyrite, and chalcopyrite. Major taxa in the vent ecosystem are Shinkaia crosnieri, Munidopsis sp., and Ashinkailepsas sp.
\end{abstract}

Keywords

Basaltic pillow lava $•$ Chemosynthetic ecosystem $•$ Hydrothermal plume $・$ The Irabu Knoll

\subsection{Location and Geological Settings}

The Irabu Knoll was first recognized through comprehensive geological and geophysical surveys in 1988 (Oshima et al. 1988; Kimura et al. 1991; Shinjo 1999). It locates at $55 \mathrm{~km}$ off the northwest of the Miyako Island on the eastern edge of the Yaeyama Graben in the Southern Okinawa Trough (Fig. 39.1). The Southern Okinawa Trough characterized by an active rifting of the Asian continental margin and the Yaeyama Graben is considered to be a key area to understand tectonics and evolution of back-arc basins. The Irabu Knoll consists of three major seamounts, East, West, and South seamounts. The East seamount has a caldera-like elliptic depression with an opening on its northwest face.

The online version of this chapter (doi:10.1007/978-4-431-54865-2_39) contains supplementary material, which is available to authorized users.

T. Fukuba $(\bowtie) \bullet$ T. Noguchi

Marine Technology and Engineering Center,

Japan Agency for Marine-Earth Science and Technology,

2-15 Natsushima-cho, Yokosuka, Kanagawa 237-0061, Japan

e-mail: bafuk@jamstec.go.jp

T. Fujii

Institute of Industrial Science, The University of Tokyo,

4-6-1 Komaba, Meguro-ku, Tokyo, Japan
The major and minor axis of the depression is ca. 600 and $400 \mathrm{~m}$, respectively. The water depth at the bottom of the depression is $1,970 \mathrm{~m}$. The West seamount has a truncated cone feature and the water depth of the seamount is ca. $1,680 \mathrm{~m}$. The South seamount has been reported as EWelongated structure by Matsumoto et al. (2001), but the accurate water depth is not determined yet. In 2000, several dives using manned submersible SHINKAI 6500 revealed the existence of hydrothermal activities at the East and the West seamounts, however, no dive has been carried out at the South seamount (Matsumoto et al. 2001). Former two seamounts were composed of fresh basaltic pillow lava, and thin sediments were covered on the pillow lava in the flank of the seamounts (Fig. 39.2a). Hydrothermal vents are located on the south face of the East seamount $\left(25^{\circ} 14.10^{\prime} \mathrm{N}, 124^{\circ} 52.89^{\prime} \mathrm{E}\right.$; water depth $\left.=1,876 \mathrm{~m}\right)$ and at the summit of the West seamount $\left(25^{\circ} 13.76^{\prime} \mathrm{N}, 124^{\circ} 52.16^{\prime} \mathrm{E}\right.$; water depth $=1,648 \mathrm{~m}$ ). Sulfide deposits collected from the West seamount are likely to be composed under rather higher sulfidation state and are mineralogically similar to those of the Kuroko deposits rather than the Bessi-type deposits (Watanabe et al. 2006). Existence of indium in the sulfide chimney, revealed using neutron activation analysis (Noguchi 2007), is consistent with geochemical 


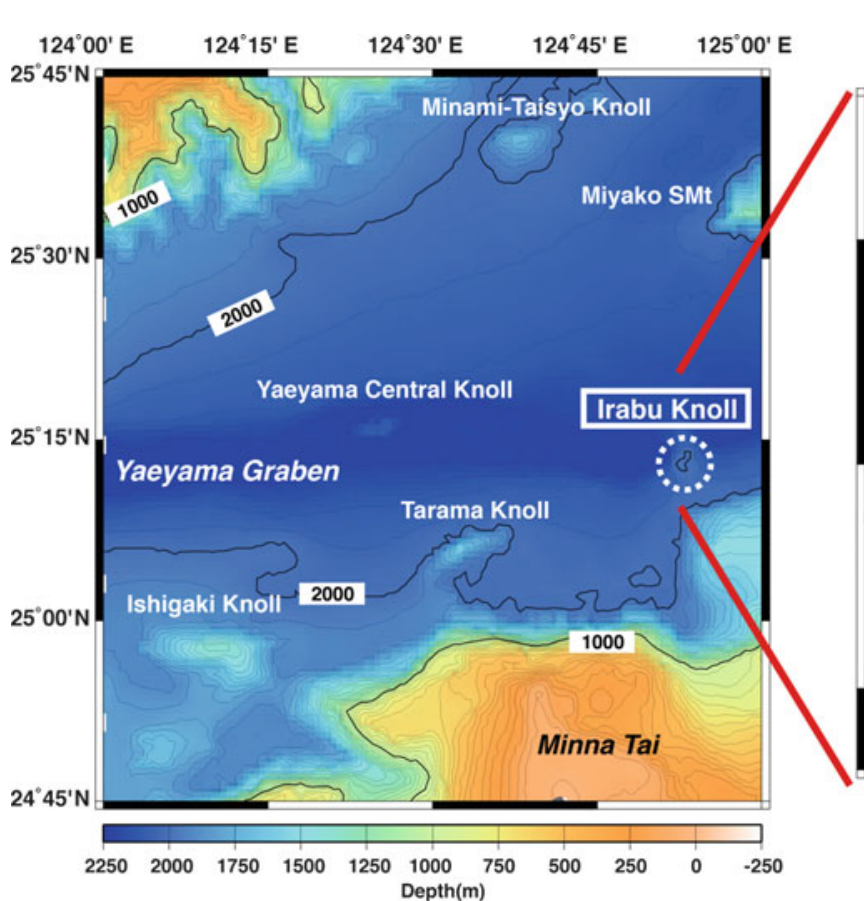

Fig. 39.1 Bathymetry of the Southern Okinawa Trough and location of the hydrothermal vents at the Irabu Knoll. $W s$ hydrothermal vents on the West seamount, $N s$ hydrothermal vents on the East seamount, $B c$

characteristic common on the basaltic lava hosted hydrothermal fields (e.g. the East Pacific Rise and the Southern Mariana Trough). To observe the hydrothermal plumes and to collect the rocks, sulfide minerals, and biological samples for geochronological studies, following three cruises were conducted in 2011 and 2012, NT11-17 (R/V NATSUSHIMA and ROV HYPER-DOLPHIN, JAMSTEC) (Fukuba 2011), NT11-20 scientific cruise in 2011 (R/V NATSUSHIMA and ROV HYPER-DOLPHIN), and YK12-05 (R/V YOKOSUKA and manned submersible SHINKAI 6500, JAMSTEC).

\subsection{Hydrothermal Activity and Biogeochemical Properties}

Clear hydrothermal fluid venting was found at the summit of the West seamount. A grid survey of hydrothermal plume using ROV HYPER-DOLPHIN found the temperature

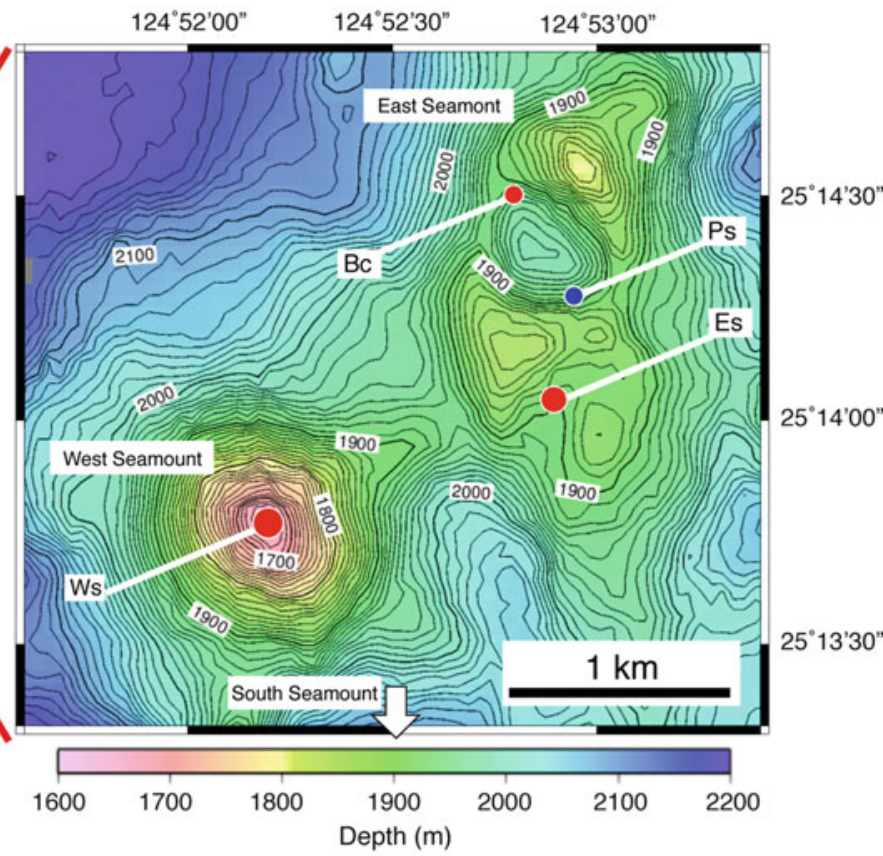

Mytiloidea colonies with weak seepage, Ps Previously reported site (Matsumoto et al. 2001). The South seamount is not shown in the bathymetric map

anomalies at three points around the rugged summit of the seamount (Suppl. 39.1). White-fluffy precipitates were observed in hydrothermal plume and covered a part of the massive sulfides and chimney structures. The highest fluid temperature in the Irabu Knoll, $67{ }^{\circ} \mathrm{C}$, was recorded at a clear smoker vent on the West seamount during 2011 survey (Fukuba 2011). Dense and diverse populations of Crustaceans dominated by Shinkaia crosnieri, Munidopsis sp. (Fig. 39.2b-d), and Ashinkailepsas sp. (Fig. 39.2d) were observed around the active chimneys. Hydrothermal chimney structures and sulfide deposits at the East seamount were smaller than those of the West seamount. The chimneys were distributed on flat terraces and cliffs at the south face of the caldera-like depression. Clear hydrothermal fluid was venting from the chimneys and gaps between rocks on cliffs. The other hydrothermal site with seepage was found at northern inside face of the depression. Small colonies of bivalves were interspersed on a rocky slope covered by thin sediment (Fig. 39.2e). 


\section{a}

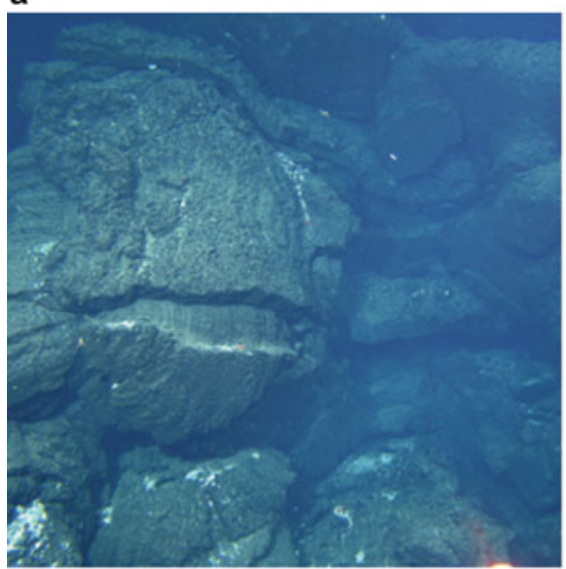

C

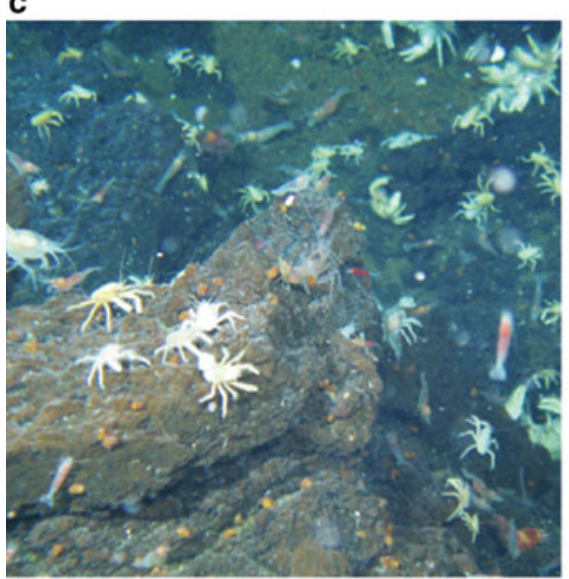

e

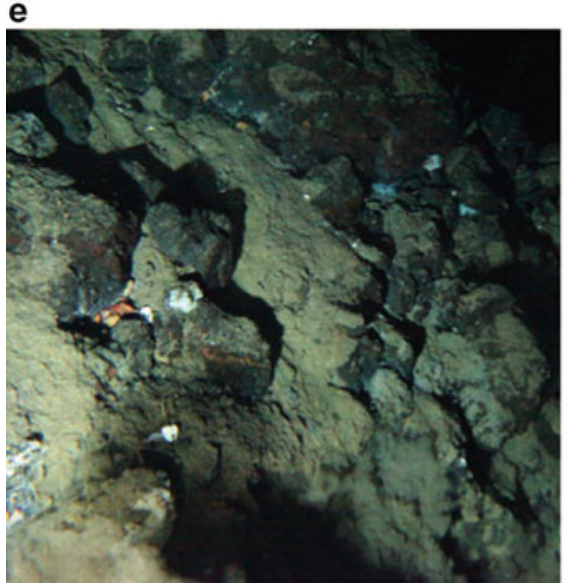

Fig. 39.2 Pictures of geological and biological feature at the Irabu Knoll. (a) Fresh basaltic pillow lava, (b) Active hydrothermal site at the West seamount, (c) Crustaceans dominated by Shinkaia crosnieri and

Acknowledgement Part of the bathymetric data was supplied from Japan Oceanographic Data Center (JODC). This work was partially supported by a Grant-in-Aid for Scientific Research on Innovative Areas (Project TAIGA, no. 20109003).

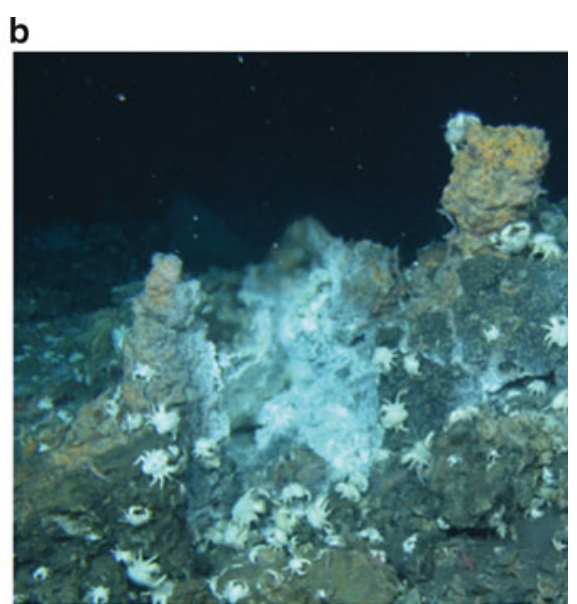

d

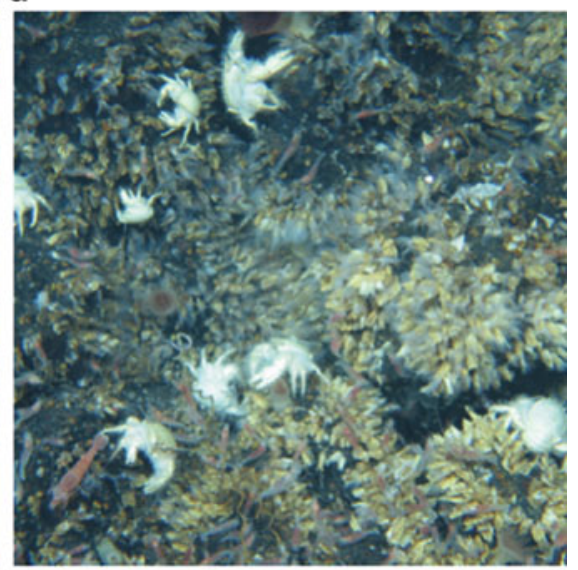

Munidopsis sp., (d) Dense colony of Ashinkailepsas sp. (e) A small colony of bivalves on the northern inside slope

Open Access This chapter is distributed under the terms of the Creative Commons Attribution Noncommercial License, which permits any noncommercial use, distribution, and reproduction in any medium, provided the original author(s) and source are credited. 


\section{References}

Fukuba T (2011) Hydrothermal plume mapping by in situ multi parameter measurements at the Yoron Knoll and the Irabu Knoll, NATSUSHIMA Cruise Report. http://www.godac.jamstec.go.jp/cat alog/data/doc_catalog/media/NT10-16_all.pdf

Kimura M, Furukawa M, Izawa E, Ishikawa M, Kuramoto S, Sakai H, Uyeda S, Markris J (1991) Report of DELP 1988 cruises in the Okinawa Trough. Part 7. Geologic investigation of the central rift in the middle to southern Okinawa Trough. Bull Earthq Res Instit Univ Tokyo 66:179-209

Matsumoto T, Kinoshita M, Nakamura M, Sibuet JC, Lee CS, Hsu SK, Oomori T, Shinjyo R, Hashimoto Y, Hosoya S, Imamura M, Ito M, Tsukuda K, Yagi H, Tatekawa K, Kagaya I, Hokakubo S, Okada T, Kimura M (2001) Volcanic and hydrothermal activities and possible "segmentation" of the axial rifting in the westernmost part of the Okinawa Trough. Preliminary results from the
YOKOSUKA/SHINKAI 6500 Lequios Cruise. JAMSTEC J Deep Sea Res 19:95-107 (in Japanese with English abstract)

Noguchi T (2007) Geochemical study on the deep and shallow submarine hydrothermal activities, Ph.D. thesis, University of the Ryukyus, Okinawa, Japan

Oshima S, Takanashi M, Kato S, Uchida M, Okazaki I, Kasuga S, Kawashiri C, Kaneko Y, Ogawa M, Kawai K, Seta H, Kato Y (1988) Geological and geophysical survey in the Okinawa Trough and the adjoining seas of Nansei Syoto. Rep Hydr Res 24:19-43 (in Japanese with English abstract)

Shinjo R (1999) Geochemistry of high Mg andesites and the tectonic evolution of the Okinawa Trough-Ryukyu arc system. Chem Geol 157:69-88

Watanabe M, Hoshino K, Shinokawa R, Takaoka Y, Fukumoto H, Shibata Y, Shinjo R, Oomori T (2006) Metallic mineralization associated with pillow basalts in the Yaeyama Central Graben, Southern Okinawa Trough, Japan. JAMSTEC Rep Res Dev 3:1-8 